\title{
Chemical Components and Antioxidative Effects of Eriobotya japonica Lindl. Leaf
}

\author{
Yun Gyeong Hwang, Jae Joon Lee, Ah Ra Kim and Myung Yul Lee*
}

Department of Food and Nutrition, Chosun University, Gwangiu 501-759, Korea

Received 7 30, 2010 /Accepted 11 17, 2010

\begin{abstract}
This study was carried out to investigate the physicochemical compositions and antioxidative effects of Eriobotrya japonoca Lindl (Loquat). The proximate compositions of the loquat leaf on a dry matter basis were $8.78 \%$ moisture content, $6.74 \%$ crude protein, $7.87 \%$ crude fat, $6.99 \%$ crude ash, $43.61 \%$ dietary fiber and $26.01 \%$ carbohydrate. In analysis of free amino acids, 16 kinds total amino acid components, 17 kinds of components were isolated from loquat. The essential amino acids contained in loquat leaf accounted for $50.15 \%$ of total amino acids, while the non-essential amino acids accounted for $49.85 \%$. In analysis of total fatty acids, only 5 kinds of acid were detected: lauric acid, myristic acid, pentadecanoic acid, stearic acid and oleic acid. The contents of vitamin A, vitamin $\mathrm{E}$ and vitamin C were $0.039 \mathrm{mg} \%, 0.096 \mathrm{mg} \%$ and $0.575 \mathrm{mg} \%$, respectively. The mineral contents of loquat leaf were greater in order of $\mathrm{Zn}<\mathrm{Mn}<\mathrm{Fe}<\mathrm{Na}<\mathrm{Mg}<\mathrm{K}<\mathrm{Ca}$. Organic acids including succinic acid, maleic acid and citric acid were detected. The major free sugars were identified as rhamose, galactose, glucose and lactose. Total polyphenol contents of loquat leaf ethanol extract were found to be 15.77 $\mathrm{mg} / \mathrm{ml}$ in $500 \mathrm{ppm}$ and $32.32 \mathrm{mg} / \mathrm{ml}$ in 1,000 ppm. Moreover, total flavonoid contents of loquat leaf ethanol extract were found to be $15.58 \mathrm{mg} / \mathrm{ml}$ in $500 \mathrm{ppm}$ and $28.65 \mathrm{mg} / \mathrm{ml}$ in 1,000 ppm. The DPPH radical scavenging activity of loquat leaf ethanol extract in 1,000 ppm was high and similar to the BHA and BHT.
\end{abstract}

Key words : Eriobotrya japanica Lindl. leaf, chemical components, total polyphenol, antioxidative effect

\section{서 론}

최근 우리나라는 생활수준의 향상으로 인하여 건강한 삶에 대한 관심이 꾸준히 증가하고 있으며, 이에 따라 질병의 예방 및 개선을 위해 동·식물 등으로부터 얻어지는 생리활성 물질 들을 이용하려는 연구가 활발히 진행되고 있다. 특히 다류의 소비가 증가하면서 식물류 중에 존재하는 생리활성 물질에 대한 관심이 높아져 국내·외적으로 이들 생리활성 물질을 함유한 신소재 식물들을 다류의 원료로 사용하려는 시도가 많이 이루어지고 있다[15].

이러한 다류에서 생리활성을 나타낼 수 있는 성분으로 항산 화 비타민 및 flavonoids를 비롯한 polyphenol류를 들 수 있 다. 페놀성 화합물은 여러 가지 식물류에 널리 분포되어 있는 것으로 알려져 있으며 일반적으로 수용성인 flavonoid류가 주 를 이루며 단순한 phenol류, phenolic acid류, phenyl propanoid류, phenol성 quinone류 등을 포함한다[18]. 이러한 생리 활성 물질들은 유지의 자동산화과정의 연쇄반응을 억제시키 는 radical scaverger나 혹은 LDL (low density lipoprotein) 산화에 의한 동맥경화, 심장병 예방, 노화 억제 등의 효과가 있는 것으로 알려져 있다[33].

비파(Eriobotrya japonica Lindl.)나무는 장미과(Resaceae)의

*Corresponding author

Tel : +82-62-230-7722, Fax : +82-62-225-7726

E-mail : mylee@mail.chosun.ac.kr
상록교목으로 높이가 $5 \mathrm{~m}$ 내외로 잎은 어긋나고 타원상 긴 난형이며, 길이는 $15 \sim 25 \mathrm{~cm}$ 로 표면에는 털이 없으며 광택 이 나고 뒷면에 털이 난다. 우리나라에서는 제주도, 경남 및 전남지방 등 온화한 기후 조건에서 주로 자생하고 있으며, 비파 잎은 예로부터 민간요법으로 청폐, 진해, 거담, 건위 및 이뇨의 효능이 있다고 하며, 폐열해소, 기관지염, 구역질, 딸 꾹질 및 부종 등에 효능이 있다고 알려져 있다[29]. 또한 중 국 및 일본에서는 만성천식에 대해 민간약으로 사용되어져 왔다[31]. 비파열매에는 carotenoid 색소를 많이 함유되어 있 으며, 특히 숙성 후 당분이 많고 유기산이 적게 함유하고 있 어 다른 과실류에 비하여 당산비가 비교적 높고 단맛이 강한 것이 특징이다[10].

비파의 기능성에 대한 국내 연구로는 항산화 및 항균활성 [30], 아질산염 소거 및 항돌연변이 효과[3], 항암효과[38], 생리 활성[22,25] 등이 보고되어 있으며, 식품화에 대한 연구로는 비파 yoghurt [14], 비파주스[4], 비파엽차의 제조[5]에 대해 보고되어 있다. 비파잎은 연중 언제나 수확이 가능하며, 다양 한 생리활성 물질을 함유하고 있어 새로운 기능성 소재로의 개발 잠재성을 지니고 있으며, 이에 따라 비파잎의 기능성에 대한 다양한 연구가 필요한 실정이다.

따라서 본 연구는 비파잎의 다양한 기능성 식품소재로의 이용성을 높이는데 있어 기초적인 자료로 활용하고자, 비파잎 의 일반성분과 영양성분을 분석하고 생리활성 효능 검증을 통 하여 기능성식품 개발 방안을 모색하고자 실시하였다. 


\section{재료 및 방법}

\section{실험재료}

본 실험에 사용된 비파잎(E. japanica Lindl. Leaf)은 2009년 7월 (주)두루시스템에서 구입하여 비파잎 뒷면의 잔털을 깨끗 이 제거한 후 $3 \sim 4 \mathrm{~cm}$ 정도로 자른 다음 냉동 건조시켜 $-70^{\circ} \mathrm{C}$ 에서 냉동보관하면서 시료로 사용하였다. 각 시험 항목에 대 한 시료의 분석은 3 회 반복 실시하였다.

\section{일반성분}

비파잎의 일반성분 분석은 Association of Official Analytical Chemists (A.O.A.C.) 방법[1]에 준하여 실시하였으 며, 수분은 $105^{\circ} \mathrm{C}$ 상압가열건조법, 조단백질은 micro-kjeldahl 법, 조지방은 soxhlet 추출법 및 조회분은 회화법으로 분석하 였고, 식이섬유소는 효소중량법(enzymatic-gravimetric method)에 의하여 분석하였다. 탄수화물은 100 에서 수분, 조단백 질, 조지방, 조회분 및 식이섬유소량을 제외한 값으로 나타내 었다.

\section{구성당}

구성당 분석은 Gancedo 방법[13]에 준하여 실시하였다. 시 료 $1 \mathrm{~g}$ 에 $80 \%$ ethanol $50 \mathrm{ml}$ 를 가하여 heating mentle에서 $75^{\circ} \mathrm{C}$ 로 5 시간 가열한 다음 Whatman filter paper (No. 2)로 여과하고 여액을 rotary vacuum evaporator에서 감압 - 농축 후 $10 \mathrm{ml}$ 로 정용하여 Ion Chromatography (DX-600, Dionex, CA, USA) 로 분석하였다. 분석조건으로 Column은 CarboPac ${ }^{\mathrm{TM}}$-PA10 analytical $(4 \times 250 \mathrm{~mm})$ 을, detection은 ED50 Integrated Amperometry를 이용하여 실시하였다. Flow rate $1.0 \mathrm{ml} / \mathrm{min}$, injection volume $20 \mu \mathrm{l}$, 이동상은 $18 \mathrm{mM} \mathrm{NaOH}$ 수용액을 사용하였다.

\section{유리 아미노산}

유리 아미노산의 분석은 시료 $2 \mathrm{~g}$ 에 ethanol $20 \mathrm{ml}$ 을 가한 후 homogenizer로 10 분 동안 교반하여 $1,900 \times g$ 에서 20 분간 원심분리 하였고, 잔사에 다시 $75 \%$ ethanol $10 \mathrm{ml}$ 를 첨가하여 homogenizer로 10 분 동안 교반한 후 $1,900 \times g$ 에서 20 분간 원 심분리 하였다. 상층액을 합하여 감압농축한 후 증류수로 용 해시켜 sulfosalicylic acid $20 \mathrm{mg}$ 을 첨가하여 $4^{\circ} \mathrm{C}$ 로 1 시간동안 방치시킨 다음 다시 $1,900 \times g$ 에서 20 분간 원심분리한 후, membrane filter $(0.2 \mu \mathrm{m})$ 로 여과시켜 아미노산 자동분석기 (S433-H, Sykam GmbH, Eresing, Germany)로 정량분석하였 다. 분석조건은 Cation separation column (LCA K07/Li, $4.6 \times 150 \mathrm{~mm}$ )을 사용하였으며, column의 온도는 $37 \sim 74^{\circ} \mathrm{C}$ 로 하였다. Flow rate는 buffer (pH 2.90 7.95) $0.45 \mathrm{ml} / \mathrm{min}$, reagent는 $0.25 \mathrm{ml} / \mathrm{min}$ 으로 하였으며, $440 \mathrm{~nm}$ 와 $570 \mathrm{~nm}$ 에서 측정하였다.

\section{구성 아미노산}

구성 아미노산의 분석은 시료 $0.5 \mathrm{~g}$ 을 $18 \mathrm{ml}$ test tube에 칭량하여 $6 \mathrm{~N} \mathrm{HCl} 3 \mathrm{ml}$ 를 가하여 감압 밀봉한 후 $120^{\circ} \mathrm{C}$ 로 setting 된 heatting block에 24시간 이상 동안 가수분해 시켰 다. 가수분해가 끝난 시료는 $50^{\circ} \mathrm{C}$ 에서 rotary evaporater로 산 을 제거한 후 sodium loading buffer로 $10 \mathrm{ml}$ 정용한 다음, 이중 $1 \mathrm{ml}$ 를 취하여 membrane filter $0.2 \mu \mathrm{m}$ 로 여과시켜 아미 노산 자동분석기(S433-H, Sykam GmbH, Eresing, Germany) 로 정량분석하였다. 분석조건으로 column은 Cation separation column (LCA K06/Na, $4.6 \times 150 \mathrm{~mm}$ )를 사용하였으며, column의 온도는 $57 \sim 74^{\circ} \mathrm{C}$ 로 하였다. Flow rate는 buffer (pH $3.45 \sim 10.85) 0.45 \mathrm{ml} / \mathrm{min}$, reagent $0.25 \mathrm{ml} / \mathrm{min}$ 으로 하였으 며, $440 \mathrm{~nm}$ 와 $570 \mathrm{~nm}$ 에서 측정하였다.

\section{지방산}

지방산 분석은 A.O.A.C.방법[1]에 준하여 시료 $5 \mathrm{~g}$ 을 warming blender에 넣고 chloroform $10 \mathrm{ml}$ 와 methanol 20 $\mathrm{ml}$ 을 가하고 2분간 균질화한 다음, chloroform $10 \mathrm{ml}$ 을 더 가한 후 30 초간 균질화 하였다. 여과 후 30 분간 방치한 후 상층 을 제거하고 무수 $\mathrm{Na}_{2} \mathrm{SO}_{4}$ 를 가하여 탈수한 다음 rotary vacuum evaporator로 감압. 농축하였다. 지방 $100 \mathrm{mg}$ 을 toluene $5 \mathrm{ml}$ 에 용해하고 Wungaarden의 방법[39]에 따라 $\mathrm{BF}_{3}$-Methanol로 메칠화하여 Gas Chromatography (GC-17A, Shimadzu, Kyoto, Japan)로 분석하였다. 분석조건은 $\mathrm{SP}^{\mathrm{TM}}-2560$ capillary column $(100 \mathrm{~m}$ length $\times 0.25 \mathrm{~nm} \mathrm{I.d.} \times$ $0.25 \mu \mathrm{m}$ film thickness)을 이용하였고, oven temperature는 $120^{\circ} \mathrm{C}$ 로 하였으며, FID detector로 검출하였다.

\section{비타민}

비타민 $\mathrm{A}$ 와 비타민 $\mathrm{E}$ 분석은 식품공전법[28]의 시험방법을 기준으로 수행하였다. 시료 $0.5 \mathrm{~g}$, ascorbic acid $0.1 \mathrm{~g}$ 및 ethanol $5 \mathrm{ml}$ 를 취하여 $80^{\circ} \mathrm{C}$ 에서 10 분간 가열한 후 $50 \% \mathrm{KOH}$ 용액 $0.25 \mathrm{ml}$ 을 첨가하고 20 분간 가열한 다음 증류수 $24 \mathrm{ml}$ 와 hexane $5 \mathrm{ml}$ 를 가하여 $1,900 \times \mathrm{g}$ 에서 20분간 원심분리 하였다. 상 징액을 분리 후 hexane $40 \mathrm{ml}$ 를 가하고 원심분리하여 상징액 을 분리한 다음 증류수를 가하여 10 분간 방치 후 하층을 제거 하였다. 이 과정을 3회 반복한 후 전 용액을 합하여 $\mathrm{Na}_{2} \mathrm{SO}_{4}$ 로 탈수하고 rotary vacuum evaporator로 hexane을 감압 - 농축 한 후 HPLC (LC-10AVP, Shimadzu, Kyoto, Japan)로 분석하 였다. 분석조건으로 column은 Shim-pack GLC-ODS (M) 25 $\mathrm{cm}$ 를 이용하였으며, flow rate $1 \mathrm{ml} / \mathrm{min}$, injection volume $10 \mu 1$ 로 하였으며, detection은 SPD-10A (UV-VIS Detector 254 $\mathrm{nm}), \mathrm{RF}-10 \mathrm{~A}$ (Spectrogluorometric Detector)를 사용하였다. 비타민 C 함량은 각 추출물을 $0.2 \mu \mathrm{m}$ membrane filter로 여과 하여 HPLC (Young-Rin Associates, Seoul, Korea)로 분석하였 으며, 분석조건으로 column은 $\mu$-Bondapak $\mathrm{C}_{18}(3.9 \times 300 \mathrm{~mm})$ 
을 사용하였고, 유속은 solvent $30 \mathrm{ml} / \mathrm{hr}$, ninhydrin $20 \mathrm{ml} / \mathrm{hr}$ 이고, 압력은 solvent $55 \mathrm{var}$, ninhydrin $12 \mathrm{bar}$ 이었다.

\section{무기질}

무기질 분석은 A.O.A.C.방법[1]에 따라 정량하였다. 시료 $0.5 \mathrm{~g}, 20 \% \mathrm{HNO}_{3} 10 \mathrm{ml}$ 및 $60 \% \mathrm{HClO}_{4} 3 \mathrm{ml}$ 를 취하여 투명해 질 때까지 가열한 후 $0.5 \mathrm{M} \mathrm{HNO}_{3}$ 으로 $50 \mathrm{ml}$ 를 정용하였다. 분석항목별 표준용액을 혼합 후 다른 vial에 $8 \mathrm{ml}$ 씩 취하여 표준용액으로 하였고, $0.5 \mathrm{M} \mathrm{HNO}_{3}$ 을 대조구로 하여 원자흡 수분광광도계(AA-6501GS, Shimadzu, Kyoto, Japan)로 분석 하였으며 분석조건은 다음과 같다. Acetylene flow rate는 2.0 $1 / \mathrm{n}$, air flow rate는 $13.5 \mathrm{l} / \mathrm{min}$ 의 조건으로 $\mathrm{Ca}(422.7 \mathrm{~nm})$, $\mathrm{Fe}(248.3 \mathrm{~nm}), \mathrm{K}(766.5 \mathrm{~nm}), \mathrm{Mg}(285.2 \mathrm{~nm}), \mathrm{Mn}(279.5 \mathrm{~nm})$, $\mathrm{Cu}(324.8 \mathrm{~nm}), \mathrm{Na}(330.2 \mathrm{~nm}), \mathrm{Zn}(213.9 \mathrm{~nm})$ 를 분석 정량하 였다.

\section{유기산}

유기산 분석은 A.O.A.C. 방법[1]에 따라 시료 $1 \mathrm{~g}$ 에 증류수 $50 \mathrm{ml}$ 를 가하여 $80^{\circ} \mathrm{C}$ 수조에서 4 시간 가열한 다음 Whatman filter paper (No. 2)로 여과하고, 여액을 rotary vacuum evaporator로 감압·농축한 후 증류수로 $10 \mathrm{ml}$ 로 정용하여 Ion Chromatography (DX-600, Dionex, CA, USA)로 분석하였다. 분석조건으로 column은 IonPac AS11-HS analytical $(4 \times 250$ $\mathrm{mm})$ 을 이용하였고, detection은 ED50 Conductivity를 사용 하였다. flow rate는 $1.0 \mathrm{ml} / \mathrm{min}$, injection volume은 $10 \mu \mathrm{l}$, 이동상은 EGC-KOH Cartridge- $38 \mathrm{mM} \mathrm{KOH}$ 수용액을 사용 하였다.

\section{시료추출}

건조된 비파잎 $100 \mathrm{~g}$ 당 $80 \%$ ethanol 1,500 ml을 첨가한 후 환류냉각관을 부착한 $65^{\circ} \mathrm{C}$ 의 heating mantle에서 3 시간씩 3 회 추출한 다음 Whatman filter paper (No.2)로 여과하였으며, 여액을 $40^{\circ} \mathrm{C}$ 수욕상에서 rotary vacuum evaporator로 용매를 제거하고 감압 - 농축한 후 시료의 산화를 방지하기 위해 $-70^{\circ} \mathrm{C}$ 에 냉동 보관하였다.

\section{총 Polyphenol 함량}

총 polyphenol 함량은 Folin-Denis법[12]에 따라 측정하였 다. Test tube에 시료 $1 \mathrm{ml}$ 과 Folin reagent $2 \mathrm{ml}$ 을 넣은 후 실온에서 3 분간 정치한 다음 $10 \% \mathrm{Na}_{2} \mathrm{CO}_{3} 2 \mathrm{ml}$ 을 첨가하였고 이를 혼합한 후 $30^{\circ} \mathrm{C}$ 에서 40 분간 정치하였으며, UV-visible spectrophotometer (UV-1601PC, Shimadzu, Kyoto, Japan)를 사용하여 $760 \mathrm{~nm}$ 에서 흡광도를 측정하였다. 표준곡선은 $\tan -$ $\mathrm{nic} \mathrm{acid}$ 를 이용하여 최종농도가 $0,0.2,0.4,0.6,0.8$ 및 1.0 $\mathrm{mg} / \mathrm{ml}$ 가 되도록 작성하였으며, 이 검량곡선으로부터 시료중 의 폴리페놀 함량을 구했다.

\section{총 flavonoid 함량}

총 flavonoid 함량은 Davis법을 변형한 방법[9]에 따라 측정 하였다. 시료 $1 \mathrm{ml}$ 에 diethylene glycol $2 \mathrm{ml}$ 을 첨가한 다음 $1 \mathrm{~N} \mathrm{NaOH} 20 \mu 1$ 을 넣고 $37^{\circ} \mathrm{C}$ water bath에서 1 시간 동안 반응 시킨 후 UV-spectrophotometer (UV-1601PC, Shimadzu, Kyoto, Japan)로 $420 \mathrm{~nm}$ 에서 흡광도를 측정하였다. 표준곡선 은 rutin을 이용하여 최종 농도가 $0,0.2,0.4,0.6,0.8$ 및 1.0 $\mathrm{mg} / \mathrm{ml}$ 가 되도록 조제하였으며, 이 검량곡선으로부터 시료 중의 플라보노이드 함량을 구했다.

\section{DHHP radical 소거능}

비파잎 추출물의 DPPH radical 소거능은 Blois의 방법[6]을 이용하여 측정하였다. 비파잎 추출물 $1 \mathrm{ml}$ 과 $0.2 \mathrm{mM} \mathrm{2,2-di-}$ phenyl-1-picrylhydrazyl (DPPH) $1 \mathrm{ml}$ 을 test tube에 취한 후 혼합하여 $37^{\circ} \mathrm{C}$ 에서 30 분간 반응시켜 UV-spectrophotometer (UV-1601PC, Shimadzu, Kyoto, Japan)를 사용하여 $517 \mathrm{~nm}$ 에 서 흡광도를 측정하였다. 이때, 활성의 비교를 위하여 합성 항산화제인 BHA와 BHT를 이용하여 동일한 방법으로 측정하 였다. 비파잎 추출물의 라디칼 소거능은 (1-시료첨가구의 흡광 도/무첨가구의 흡광도)× 100 에 의하여 계산하여 나타냈다.

\section{통계처리}

본 실험은 독립적으로 3 회 이상 반복 실시하여 얻은 결과로 결과는 SPSS 통계 Package를 이용하여 일원배치 분산분석 (one-way analysis of variance)을 실시 한 후 $p<0.05$ 수준에서 Tukey's test에 의하여 각 실험군의 평균치간의 유의성을 검정 하였다.

\section{결과 및 고찰}

\section{일반성분}

본 실험에서 사용한 비파잎의 일반성분 함량은 Table 1 과 같다. 일반성분은 건량 기준(dry basis)으로 수분 함량 $5.78 \%$, 조단백질 $6.74 \%$, 조지방 $7.87 \%$, 조회분 $6.99 \%$, 식이섬유소 $43.61 \%$, 탄수화물 $29.01 \%$ 였다. Bae와 Shim [2]이 한국산 비파 의 부위별 일반성분을 습량기준으로 분석한 결과 비파잎의 수분 함량은 $48.7 \%$, 조단백질 $5.23 \%$, 조지방 $3.25 \%$, 조회분 $5.71 \%$ 로 나타났다. 또한 Lee와 Kim [30]이 비파잎의 일반성분 을 분석한 결과 수분 함량은 $59.13 \%$, 조단백 $3.37 \%$, 조지방 $0.26 \%$, 조회분 $3.43 \%$ 로 나타났다. Bae 등[5]이 채취시기별로 볶음처리한 비파잎의 일반성분 분석결과 2 월 중순에 채취한 비파엽차의 경우 1 4차 볶음에서 수분이 $28.30 ~ 1.50 \%$, 조단 백질 $6.18 \sim 10.75 \%$, 조지방 $4.51 \sim 7.50 \%$, 회분 $3.26 \sim 5.84 \%$ 로 나타났으며, 10 월 중순에 채취한 비파엽차의 경우 수분이 $36.10 \sim 2.50 \%$, 조단백질 $5.66 \sim 10.42 \%$, 조지방 $6.02 \sim 8.58 \%$, 회 분 $2.49 \sim 6.43 \%$ 로 나타났다. 볶음 정도가 많을수록 수분 함량 
Table 1. Proximate compositions of E. japonica Lindl. leaf (\% dry matter basis)

\begin{tabular}{lc}
\hline \multicolumn{1}{c}{ Items } & E. japonica Lindl. leaf \\
\hline Moisture & $5.78 \pm 0.21^{\mathrm{b}}$ \\
Crude protein & $6.74 \pm 0.18$ \\
Crude fat & $7.87 \pm 0.33$ \\
Crude ash & $6.99 \pm 0.27$ \\
Dietary fiber & $43.61 \pm 2.42$ \\
Carbohydrate $^{\mathrm{a}}$ & $29.01 \pm 1.54$
\end{tabular}

${ }^{a}$ Carbohydrate $=100$-(Moisture+Crude protein+Crude fat+Crude ash+Dietary fiber).

${ }^{\mathrm{b}}$ All values are expressed as mean $\pm \mathrm{SE}$ of triplicate determinations.

은 감소하였고, 수분 함량의 감소로 인하여 조단백질 및 조지 방 등은 증가하였다.

본 실험의 비파잎이 선행연구 결과에 비하여 조단백질, 조 지방, 조회분의 함량이 더 높게 나타났다. 이러한 성분의 차이 는 비파의 품종 및 재배환경, 비파잎의 채취 시기, 건조상태의 차이로 기인 된 것으로 사료된다.

\section{구성당}

비파잎의 구성당 함량은 Table 2 와 같다. 총 4 종의 구성당이 검출되었으며, 이중 rhamnose가 $3,391.84 \mathrm{mg} / 1$ 로 제일 많이 검출되었으며, galactose $663.27 \mathrm{mg} / \mathrm{l}$, glucose $651.65 \mathrm{mg} / \mathrm{l}$, lactose $662.40 \mathrm{mg} / 1$ 검출되었다. Bae와 Shim의 연구[2]에 의 하면 비파잎의 유리당은 총 2종의 sucrose와 rhamnose가 검출 되었고, 각각 $0.87 \%$ 와 $0.15 \%$ 로 나타났으며, Bae 등[5]의 보고 에서 비파엽차의 유리당 함량은 fructose, glucose 및 xylose 등의 순으로 높게 나타났다고 하였다. 또한 Cha 등[8]의 연구 에서 동백잎의 유리당은 glucose, fructose, sucrose, maltose가 검출되었다고 보고하였다. 그러나 본 실험에서는 rhamnose, galactose, glucose, fructose, ribose, lactose만을 분석하였으 며, 본 실험에 사용 된 비파잎의 구성당과 다소 차이가 있는 것으로 사료된다.

\section{유리 아미노산}

비파잎의 유리 아미노산의 함량은 Table 3과 같다. 총 16종 의 유리 아미노산이 검출되었으며, 총 유리 아미노산의 함량 은 $50.59 \mathrm{mg} \%$ 였다. 그 중 glutamic acid 함량이 $11.30 \mathrm{mg} \%$ 로

Table 2. Contents of free sugars in E. japonica Lindl. leaf

$(\mathrm{mg} / \mathrm{l})$

\begin{tabular}{lc}
\hline Free sugar & Content \\
\hline Rhamnose & $3,391.84 \pm 5.48^{\mathrm{a}}$ \\
Galactose & $663.27 \pm 2.62$ \\
Glucose & $651.65 \pm 3.85$ \\
Lactose & $662.40 \pm 2.64$ \\
\hline
\end{tabular}

${ }^{\mathrm{b}}$ All values are expressed as mean $\pm \mathrm{SE}$ of triplicate determinations.
Table 3. Contents of free amino acids in E. japonica Lindl. leaf

\begin{tabular}{lrc}
\hline Amino acid & $\%$ & Content $(\mathrm{mg} \%)$ \\
\hline Phosphoserine & 7.45 & $3.77 \pm 0.08^{\mathrm{b}}$ \\
Aspartic acid & 6.39 & $3.23 \pm 0.28$ \\
Threonine & 1.36 & $0.69 \pm 0.09$ \\
Serine & 1.77 & $0.90 \pm 0.62$ \\
Asparagine & 17.84 & $9.02 \pm 0.34$ \\
Glutamic acid & 22.33 & $11.30 \pm 0.44$ \\
Gylcine & 2.20 & $1.11 \pm 0.06$ \\
Alanine & 8.96 & $4.53 \pm 1.20$ \\
Valine & 3.46 & $1.75 \pm 0.07$ \\
Isoleucine & 0.85 & $0.43 \pm 0.12$ \\
Tyrosine & 2.42 & $1.22 \pm 0.65$ \\
Phenylalanine & 2.32 & $1.17 \pm 0.21$ \\
$\gamma$-amino-n-butyric acid & 16.41 & $8.30 \pm 1.10$ \\
Anserine & 1.75 & $0.89 \pm 0.21$ \\
Ethanolamine & 1.44 & $0.73 \pm 0.24$ \\
Arginine & 3.04 & $1.54 \pm 0.62$ \\
\hline Total AA $^{\mathrm{a}}$ & 100 & $50.59 \pm 2.34$ \\
\hline
\end{tabular}

${ }^{\mathrm{a}}$ Total AA: Total amino acid.

${ }^{\mathrm{b}}$ All values are expressed as mean $\pm \mathrm{SE}$ of triplicate determinations.

가장 높았으며, asparagine $9.02 \mathrm{mg} \%, \gamma$-amino-n-butyric acid $8.30 \mathrm{mg} \%$, alanine $4.53 \mathrm{mg} \%$, phosphoserine $3.77 \mathrm{mg} \%$, aspartic acid $3.23 \mathrm{mg} \%$ 순으로 높게 나타났다. Bae와 Shim [2]이 한국산 비파의 부위별 유리 아미노산을 분석한 결과 비 파잎에서 총 21종의 유리 아미노산이 검출되었으며, glutamic acid가 $280.22 \mathrm{mg} \%$ 로 가장 높게 나타났다. 그 다음으로 cystine $147.60 \mathrm{mg} \%$, proline $131.82 \mathrm{mg} \%$, sarcosine $131.07 \mathrm{mg} \%$ 순으로 높게 나타났다고 보고하였다. 또한 Bae 등[5] 이 비파 엽차 1,2 및 3 차 침출액에 대한 유리 아미노산을 분석한 결과 각각 11 종, 20 종 및 8 종의 유리아미노산이 검출되었으며, 1 차 침출액의 경우 dl-allohydroxylysine, serine, 1-methylhistidine의 순으로 높게 나타났고, 2차 침출액의 경우 dl-allohydorxylysine, phophoethanolamine, phosphoserine 순으로 높게 나타났으며, 3차 침출액의 경우 phosphoserin, phosphoethanolamine, a-aminoadipic acid 순으로 높게 나타났다 고 보고하여 본 실험에 사용된 비파잎과 비교하였을 때 주요 유리 아미노산의 종류와 함량이 다르게 나타났다. 이는 본 실 험과는 다르게 비파잎의 침출액으로 유리 아미노산의 함량을 분석하였기 때문으로 여겨진다. Jung 등[23]의 보고에 의하면 감잎에서는 alanine, cystine, proline, valine, threonine의 순으 로 함량이 높았으며, 녹차 잎에서는 alanine, serine, valine, glutamic acid, proline의 순으로 함량이 높았다고 보고하였는 데 이는 차의 종류에 따라 유리 아미노산의 조성이 다르기 때문이라 생각된다. 동백잎에서는 성엽 덖음차의 경우 glutamic acid가 가장 많이 함유되어 있었고, aspartic acid, threonine, tyrosine, arginine 등의 순으로 나타났으며[8], 비파잎의 주요 유리 아미노산의 구성과 유사하였다. 
구성 아미노산

비파잎의 구성 아미노산 함량은 Table 4 와 같다. 총 17 종의 구성 아미노산이 검출되었으며, 총 구성 아미노산 함량은 $3,789.122 \mathrm{mg} \%$ 였다. 구성 아미노산의 경우 histidine 함량이 $501.26 \mathrm{mg} \%$ 로 가장 높았으며, glutamic acid, leucine, aspatic acid, valine, arginine의 순이었다. 구성아미노산 중 필수아미 노산은 $1,869.97 \mathrm{mg} \%$ 로 histidine, leucine, valine, phenylalanine, lysine, threonine, methionine 순이었으며, 총 아미노 산에 대한 필수 아미노산의 비율은 $50.15 \%$ 로 높게 차지하는 것으로 나타났다. 동백잎에 함유된 구성 아미노산은 총 16 종 검출 되었고, 그 중 histidine이 채취시기에 따라 161.9 238.7 $\mathrm{mg} \%$ 로 가장 많이 함유되었으며, 총 아미노산 중 필수 아미노 산은 56.37 $63.88 \%$ 차지하는 것으로 보고하여[24], 비파잎의 총 아미노산에 대한 필수 아미노산의 비율과 유사하게 나타났 다. 아미노산은 종류에 따라 특유의 맛을 지니고 있는데, 이는 식품학적인 면에서 볼 때 중요한 의미를 가지고 있다. 단맛을 내는 아미노산으로는 glycine, alanine, valine, proline, hydroxy proline, histidine, serine, tryptophan 등이 있고, 쓴맛 을 내는 아미노산류로는 isoleucine, arginine, 무미의 아미노 산으로는 leucine, 감칠맛의 아미노산으로는 glutamic acid (Na+salt)가 해당된다[27]. 본 실험에서는 비파잎의 구성 아미 노산 중 단맛을 내는 아미노산인 glycine, alanine, valine, pro-

Table 4. Contents of total amino acids in E. japonica Lindl. leaf

\begin{tabular}{|c|c|c|}
\hline Amino acid & $\%$ & Content $(\mathrm{mg} \%)$ \\
\hline \multicolumn{3}{|l|}{ Essential } \\
\hline Threonine & 4.50 & $167.67 \pm 1.46^{\mathrm{c}}$ \\
\hline Valine & 6.98 & $260.13 \pm 0.78$ \\
\hline Methionine & 0.50 & $18.76 \pm 0.09$ \\
\hline Isoleucine & 4.48 & $166.91 \pm 1.30$ \\
\hline Leucine & 9.74 & $363.26 \pm 0.76$ \\
\hline Phenylalanine & 6.01 & $224.01 \pm 0.46$ \\
\hline Histidine & 13.44 & $501.26 \pm 3.11$ \\
\hline Lysine & 4.50 & $167.97 \pm 2.21$ \\
\hline \multicolumn{3}{|l|}{ Non-essential } \\
\hline Aspatic acid & 9.49 & $354.08 \pm 2.14$ \\
\hline Serine & 4.80 & $179.05 \pm 1.07$ \\
\hline Glutamic acid & 11.49 & $428.32 \pm 3.20$ \\
\hline Proline & 3.49 & $130.25 \pm 0.42$ \\
\hline Glycine & 5.63 & $210.07 \pm 0.62$ \\
\hline Alanine & 5.61 & $209.33 \pm 0.13$ \\
\hline Cystine & 3.67 & $136.86 \pm 0.34$ \\
\hline Tyrosine & 2.52 & $93.82 \pm 0.21$ \\
\hline Arginine & 3.15 & $117.38 \pm 0.23$ \\
\hline Total $\mathrm{AA}^{\mathrm{a}}$ & 100.00 & $3,789.122 \pm 8.21$ \\
\hline Total EAA ${ }^{b}$ & 50.15 & $1,869.97 \pm 6.20$ \\
\hline $\mathrm{EAA} / \mathrm{AA}(\%)$ & & $50.15 \pm 0.42$ \\
\hline
\end{tabular}

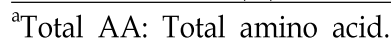

${ }^{b}$ Total EAA: Total essential amino acid.

${ }^{c}$ All values are expressed as mean \pm SE of triplicate determinations. line, histidine, serine의 함량은 $1,490.09 \mathrm{mg} \%$ 였으며, 쓴맛 을 내는 isoleucine, arginine의 함량은 $284.29 \mathrm{mg} \%$ 이며, 감 칠맛을 내는 glutamic acid의 함량은 $428.32 \mathrm{mg} \%$ 였다. 비파 잎과 동백잎을 비교하였을 때 아미노산의 비율은 다르지만 좋은 맛을 내는 glutamic acid 및 aspartic acid가 함유되어 있을 뿐만 아니라 필수아미노산을 비롯한 기타 아미노산도 골고루 함유되어 있어 이들이 차의 맛에 직접적으로 관여하 고 또 영양학적 측면에서도 중요한 의미가 있는 것으로 생 각된다.

\section{지방산}

비파잎의 지방산 조성은 Table 5 와 같다. 구성 지방산 중 포화지방산은 stearic acid가 $41.54 \%$ 로 가장 많이 함유하고 있 었으며, lauric acid $12.00 \%$, myristic acid $11.13 \%$, pentadecanoic acid $41.54 \%$ 순으로 검출되었다. 불포화지방산은 oleic acid 만 검출되었으며, 총 지방산 함량의 $27.90 \%$ 를 함유하고 있었다. Jeong 등[20]은 헛개나무잎차의 지방산을 분석한 결과 발효차에서 linolenic acid $40.18 \%$ 로 가장 많이 함유하고 있었 으며, 그 다음으로 palmitic acid $19.60 \%$, linoleic acid $7.80 \%$ 차지하였다. 또한 볶음차에서는 palmitic acid가 $26.92 \%$ 로 가 장 높았으며, linolenic acid $20.83 \%$, oleic acid $12.50 \%$ 로 나타 났다고 보고하였다. 또한 밤잎의 지방산 조성을 분석한 결과 7 종이 확인되었으며, 포화지방산 $35.21 \%$, 불포화지방산 $64.79 \%$ 를 나타내었다. Linoleic acid가 $36.86 \%$ 로 가장 높았으 며, linolenic acid $22.53 \%$, palmitic acid $10.32 \%$, steraric acid $10.10 \%$ 순으로 검출되었다[21]. 따라서 잎차의 종류에 따라 지방산의 조성은 각기 다른 것으로 판단되며, oleic acid는 혈 중 중성지방 및 콜레스테롤을 저하시켜 동맥경화와 같은 성인 병 예방에 유효한 것으로 알려져 있어[16] oleic acid 함량이 높게 나타난 비파잎차도 성인병 예방에 도움을 줄 수 있을 것으로 사료된다.

Table 5. Compositions of fatty acids of E. japonica Lindl. leaf

\begin{tabular}{lc}
\hline Fatty acid & Composition $(\%)$ \\
\hline Saturates & \\
Lauric acid (C12:0) & $12.00 \pm 0.03^{\mathrm{c}}$ \\
Myristic acid (C14:0) & $11.13 \pm 0.04$ \\
Pentadecanoic acid (C15:0) & $7.43 \pm 0.24$ \\
Stearic acid (C18:0) & $41.54 \pm 1.01$ \\
\hline Polyenes & \\
Oleic acid (C18:1n9c) & $27.90 \pm 0.35$ \\
\hline Total $^{\text {a }}$ & $100.00 \pm 0.75$ \\
\hline SFA $^{\mathrm{a}}$ & $72.10 \pm 0.25$ \\
PUFA $^{\mathrm{b}}$ & $27.90 \pm 0.14$ \\
PUFA/SFA & $0.39 \pm 0.06$ \\
\hline
\end{tabular}

${ }^{a}$ SFA: Saturated fatty acids.

${ }^{b}$ PUFA: Polyunsaturated fatty acids.

${ }^{c}$ All values are expressed as mean $\pm S E$ of triplicate determinations. 


\section{비타민}

비파잎의 비타민 $\mathrm{A}, \mathrm{E}$ 및 $\mathrm{C}$ 의 함량을 분석한 결과는 Table 6과 같다. 비타민 $\mathrm{A}$ 는 $0.039 \mathrm{mg} \%$, 비타민 $\mathrm{E}$ 는 $0.096 \mathrm{mg} \%$, 비타민 $\mathrm{C}$ 는 $0.575 \mathrm{mg} \%$ 로 검출되었다. 비타민 $\mathrm{A}, \mathrm{E}$ 및 $\mathrm{C}$ 는 항산화 비타민으로 알려져 있으며, 이들은 주로 활성산소를 제거하는 기능을 담당한다. 특히 비타민 $\mathrm{E}$ 는 혈액, 세포벽 및 세포내에서 지방질의 산화를 막는 강력한 항산화 영양소로 알려져 있다. Bae와 Shim [2]의 연구에서 비파잎의 비타민 C 함량이 $0.68 \mathrm{mg} \%$ 나타났다고 보고하여 본 실험에 사용된 비 파잎과 유사한 결과를 보였다. 그러나 헛개나무잎차의 비타민 $\mathrm{C}$ 의 함량은 발효차의 경우 $133 \mathrm{mg} \%$, 볶음차에 $130 \mathrm{mg} \%$ 로 검출되었으며[20], 밤잎의 비타민 C 함량은 $12.5 \mathrm{mg} \%$ 로 나타 났다고 보고하였다[21]. 비록 비파잎은 헛개나무잎과 밤잎에 비하여 비타민 C의 함량은 적으나, 항산화 비타민으로 알려진 비타민 A와 $\mathrm{E}$ 도 함유하고 있어 생체내에서 산화적 스트레스 (oxidative stress)를 완화시켜줄 수 있을 것이라 사료된다.

\section{무기질}

비파잎의 무기질 함량은 Table 7과 같다. 총 8종의 무기질 성분이 검출되었으며, 이 중 $\mathrm{Ca}$ 함량이 $1,892.60 \mathrm{mg} \%, \mathrm{~K}$ 함량 이 $1,244.90 \mathrm{mg} \%$ 로 많이 검출되었다. 다음으로 $\mathrm{Mg}, \mathrm{Na}, \mathrm{Fe}$, $\mathrm{Mn}, \mathrm{Zn}$ 순이었고 $\mathrm{Cu}$ 의 함량은 미량 함유하는 것으로 나타났 다. Bae와 Shim [2]의 연구에서 비파잎의 무기질 함량은 $\mathrm{Ca}$ 2,458 ppm, K 1,480 ppm 및 Na 95.7 ppm 순으로 높게 나타났 다. 또한 Bae 등[5]의 연구에서는 2월 중순에 채취한 비파엽차 의 경우 $1 \sim 4$ 차 볶음에서 $\mathrm{K}$ 의 함량은 2,120.6 39,916.8 ppm, $\mathrm{Ca}$ 의 함량은 $439.4 \sim 8,268.8 \mathrm{ppm}$ 검출되었으며, 10 월에 채취

Table 6. Contents of vitamin A, E and C in E. japonica Lindl. leaf

$(\mathrm{mg} \%)$

\begin{tabular}{cc}
\hline Vitamin & Content \\
\hline A & $0.039 \pm 0.001^{\mathrm{a}}$ \\
E & $0.096 \pm 0.002$ \\
C & $0.575 \pm 0.004$ \\
\hline
\end{tabular}

${ }^{a}$ All values are expressed as mean \pm SE of triplicate determinations.

Table 7. Contents of minerals in E. japonica Lindl. leaf

$(\mathrm{mg} \%)$

\begin{tabular}{cr}
\hline Mineral & \multicolumn{1}{c}{ Content } \\
\hline $\mathrm{Ca}$ & $1892.60 \pm 8.20^{\mathrm{b}}$ \\
$\mathrm{Fe}$ & $27.67 \pm 0.12$ \\
$\mathrm{~K}$ & $1244.90 \pm 5.27$ \\
$\mathrm{Mg}$ & $150.10 \pm 2.10$ \\
$\mathrm{Mn}$ & $17.02 \pm 0.32$ \\
$\mathrm{Cu}$ & $0.57 \pm 0.18$ \\
$\mathrm{Na}$ & $59.56 \pm 0.32$ \\
$\mathrm{Zn}$ & $4.08 \pm 0.04$ \\
\hline
\end{tabular}

${ }^{a}$ All values are expressed as mean \pm SE of triplicate determinations.
한 비파엽차의 경우 $\mathrm{K}$ 의 함량은 1,684 23,950 ppm, $\mathrm{Ca}$ 의 함 량은 $348.8 \sim 4,961.3 \mathrm{ppm}$ 검출되었고, $\mathrm{Na}, \mathrm{Fe}, \mathrm{Zn}, \mathrm{Cu}$ 의 순으 로 낮게 나타났다고 보고하였다. 이는 비파잎의 주요 구성 무 기질이 $\mathrm{Ca}$ 과 $\mathrm{K}$ 으로 본 실험과 유사하게 나타났다. 항산화 무 기질로 알려진 $\mathrm{Se}, \mathrm{Fe}, \mathrm{Mn}, \mathrm{Zn}$ 및 $\mathrm{Cu}$ 등은 종류에 따라 항산화 계에 미치는 작용기전은 차이가 있으며, $\mathrm{Se}$ 의 경우 생체 내에 서 glutathione peroxidase의 cofactor로 작용하는 것으로 알려 져 있다[34]. 또한 $\mathrm{Fe}$ 는 경우 $\mathrm{H}_{2} \mathrm{O}_{2}$ 를 제거하여 catalase의 구성 성분으로 작용하여 체내에서 항산화 작용을 나타내지만 과량 섭취시 fenton 반응을 촉진하는 pro-oxidant로 작용하는 양면 성을 가지고 있다[17]. $\mathrm{Mn}$ 은 $\mathrm{Mn}-\mathrm{SOD}$ 의 구성성분으로서 free radical을 제거하는데 관여하며 결핍 시 미토콘드리아내의 지 질과산화물이 증가한다고 보고되었다[7]. $\mathrm{Cu}$ 는 SOD 효소의 보조인자이며 헤모글로빈 생성에 필수영양소이지만 과량섭 취 시 $\mathrm{Fe}$ 와 마찬가지로 pro-oxidant로 작용하게 된다[37]. $\mathrm{Cu}$ 와 $\mathrm{Zn}$ 은 체내에서 metallothionein에 대해 서로 경쟁적인 관 계에 있으며, 상호 길항작용으로 체내에서 항상성을 유지하는 것으로 알려져 있다[11]. 비파잎 중에 이러한 항산화 무기질이 함유되어 있어 인체의 생리기능에 유효한 영향을 미칠 것으로 사료된다.

\section{유기산}

비파잎의 유기산 함량은 Table 8과 같다. 총 3종의 유기산이 검출되었으며, 이 중 succinic acid 함량이 $24,343.57 \mathrm{mg} / 1$ 로 가장 많았고, 다음으로 citric acid 2,964.87 mg/l, maleic acid $2,538.59 \mathrm{mg} / 1$ 순으로 검출되었다. Bae와 Shim의 연구[2]에 의하면 비파잎에서 oxalic acid $1,693.70 \mathrm{mg} \%$, malic acid 47.81 $\mathrm{mg} \%$, citric acid $10.63 \mathrm{mg} \%$ 순으로 나타났으며, 헛개나무잎 차에서는 발효차의 경우 oxalic acid $631.26 \mathrm{mg} \%$, citric acid $445.31 \mathrm{mg} \%$, malonic acid $310.47 \mathrm{mg} \%$ 검출되었으며, 볶음차 의 경우 citric acid $660.05 \mathrm{mg} \%$, oxalic acid $424.89 \mathrm{mg} \%$, malonic acid $362.16 \mathrm{mg} \%$ 순으로 나타났다[20]. 또한 Park 등[32] 이 보고한 우롱차에서는 fumaric acid, citric acid, malic acid, maleic acid, oxalic acid, succinic acid 순으로 총 6종 검출되었 는데, 이는 차 잎의 종류에 따라 유기산의 조성에 차이를 보이 는 것으로 사료된다.

\section{총 polyphenol 함량}

본 실험에 사용한 비파잎 추출물의 농도별 총 polyphenol

Table 8. Contents of organic acids in E. japonica Lindl. leaf

\begin{tabular}{cc} 
& $(\mathrm{mg} / \mathrm{l})$ \\
\hline Oragnic acid & Content \\
\hline Succinic acid & $24,343.57 \pm 10.85^{\mathrm{a}}$ \\
Maleic acid & $2,538.59 \pm 7.20$ \\
Citric acid & $2,964.87 \pm 9.04$ \\
\hline
\end{tabular}

${ }^{a}$ All values are expressed as mean \pm SE of triplicate determinations. 
함량은 Table 9와 같다. 비파잎 에탄올 추출물 $500 \mathrm{ppm}$ 과 $1,000 \mathrm{ppm}$ 에서 각각 $15.77 \mathrm{mg} / \mathrm{ml}$ 와 $32.32 \mathrm{mg} / \mathrm{ml}$ 함유하고 있었으며, 1,000 ppm에서 약 2배 정도 높게 나타났다. Jeong 등[22]은 비파엽 열수 추출물에서의 polyphenol 함량은 28.91 $\mathrm{mg} / \mathrm{g}$ 이었으며, 부위별 비파 메탄올 추출물 중 방사선 조사 비파잎에서 $85.0 \mathrm{mg} / \mathrm{g}$, 방사선 비조사 비파잎에서 $94.2 \mathrm{mg} / \mathrm{g}$ 함유하고 있다고 보고하였다[25]. 녹차와 보이차 메탄올 추출 물은 각각 $10.15 \mathrm{~g} / 100 \mathrm{~g}$ 과 $6.00 \mathrm{~g} / 100 \mathrm{~g}$ 함유하는 것으로 보고 하였으며[11], 녹차와 발효차 열수 추출물에서는 각각 35.7 $46.8 \mathrm{~g} / 100 \mathrm{~g}$ 와 23.5 23.9 g/100g 함유한다고 보고하였다[32]. 또한 Kim 등[24]은 동백잎의 총 polyphenol 함량은 0.47 $0.67 \%$ 로 채취시기가 늦어질수록 증가하는 것으로 나타났다고 보고하였다. Phenolic compound는 식물의 대표적인 2차 대사 산물로 hydroxyl기를 가지는 방향족 화합물로 다양한 생리활 성에 관여하는 것으로 알려져 있으며, 항산화 활성은 페놀성 화합물의 종류나 함량이 미치는 영향이 큰 것으로 알려져 있 다[35]. 연구결과 비파잎 에탄올 추출물의 총 polyphenol 함량 이 다량 검출된 것으로 보아 체내에서 항산화 작용을 할 것으 로 사료된다.

\section{총 flavonoid 함량}

비파잎 추출물의 농도별 총 flavonoid 함량은 Table 9 와 같 다. $500 \mathrm{ppm}$ 에서 $15.58 \mathrm{mg} / \mathrm{ml}, 1,000 \mathrm{ppm}$ 에서 $28.65 \mathrm{mg} / \mathrm{ml}$ 으로 나타났다. Jeong 등[22]의 연구에서 비파엽 열수 추출물 중 총 flavonoid 함량은 $10.54 \mathrm{mg} / \mathrm{g}$ 이었으며, Lee와 Kim [30] 의 생잎, 동결건조 및 가열 건조한 잎의 에탄올 추출물에서 flavonoid 함량은 각기 $110.3 \mathrm{mg} / \mathrm{g}, 90.9 \mathrm{mg} / \mathrm{g}$ 및 $76.4 \mathrm{mg} / \mathrm{g}$ 으로 각각 함유하였다. 녹차잎 열수 추출물에서는 $413.3 \mu \mathrm{g} / \mathrm{g}$, 1 년 저장한 녹차 열수추출물은 $345.1 \mathrm{ug} / \mathrm{g}$ 로 저장기간이 길어 짐에 따라 flavonoid 함량이 적어지는 것으로 나타났다[36]. Flavonoids는 직접 항산화 효소활성을 증가시키거나 free radical damage를 촉진하는 $\mathrm{Fe}, \mathrm{Cu}$ 이온과 안정적 금속이온 복합 체를 형성하고 free radical을 직접 scavenging하여 세포막과 세포내 물질을 보호한다[19]. 따라서 polyphenol 및 flavonoid 가 함유되어 있는 비파잎은 항산화 무기질과 함께 체내 항산 화계에 영향을 미칠 것으로 사료된다.

Table 9. Contents of total polyphenol and flavonoid in E. japonica Lindl. leaf

\begin{tabular}{ccc}
\hline $\begin{array}{c}\text { Concentration } \\
(\mathrm{ppm})\end{array}$ & $\begin{array}{c}\text { Total polyphenol } \\
\text { contents }(\mathrm{mg} / \mathrm{ml})\end{array}$ & $\begin{array}{c}\text { Total flavonoid } \\
\text { contents }(\mathrm{mg} / \mathrm{ml})\end{array}$ \\
\hline 500 & $15.77 \pm 0.37^{1 \mathrm{~b} 2)}$ & $15.58 \pm 0.46^{\mathrm{b}}$ \\
1,000 & $32.32 \pm 0.25^{\mathrm{a}}$ & $28.65 \pm 0.17^{\mathrm{a}}$ \\
\hline
\end{tabular}

${ }^{1)}$ All values are expressed as mean \pm SE of triplicate determinations.

${ }^{2)}$ Means in the same column not sharing a common letter are significantly different $(p<0.05)$ by Tukey's test.

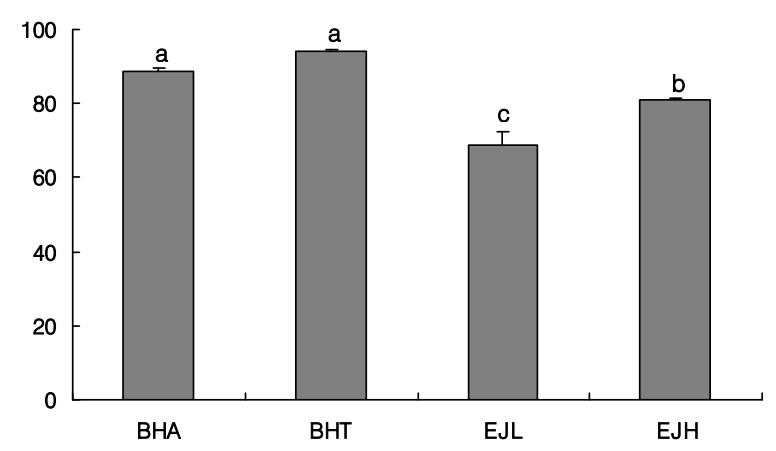

Fig. 1. DPPH radical scavenging activity of $E$. japonica Lindl. leaf ethanol extracts depending on concentration. BHA: butylated hydroxyanisole 500 ppm, BHT: butylated hydroxytouene 500 ppm. EJL: E. japonica Lindl. leaf ethanol extract 500 ppm. EJH: E. japonica Lindl. leaf ethanol extract 1,000 ppm. ${ }^{\mathrm{a}, \mathrm{b}, \mathrm{c}}$ Different superscript letters indicate significant differences at $p<0.05$ by Tukey's test.

\section{DPPH radical 소거능}

비파잎의 DPPH radical 소거능은 Fig. 1과 같다. $500 \mathrm{ppm}$ 에 서 $68.26 \%, 1,000 \mathrm{ppm}$ 에서 $80.53 \%$ 소거능을 보였으며, 이는 농도가 증가함에 따라 항산화 활성도가 증가되는 것을 알 수 있었다. 특히 1,000 ppm에서 대조구인 $500 \mathrm{ppm}$ BHT 및 BHA 와 비슷한 수준으로 높은 항산화 활성이 나타났다. Lee와 Kim [30]의 연구에서 $80 \%$ 에탄올 추출물이 열수 추출물보다 더 높은 radical 소거활성을 보였으며, 특히 생잎에서 $\mathrm{SC}_{50}$ 이 1.71 $\mathrm{mg} / \mathrm{ml}$ 로 가장 높은 활성을 보였다고 하였다. 또한 녹차잎 및 보이차잎 메탄올 추출물에서 전자공여능은 각각 $80.81 \%$ 와 $42.43 \%$ 로 나타났다고 하였으며[36], polyphenol 함량이 높을 수록 전자공여능이 높고 추출시간이 증가할수록 그 효능이 크게 나타나는 경향이 있다고 보고되었다[26]. 따라서 비파잎 은 항산화 물질을 함유하고 있어 DPPH radical 소거능 활성이 뛰어나 혈청 및 지방조직 중 지질 대사에 영향을 미칠 것으로 사료된다.

\section{References}

1. A.O.A.C. 1995. Official methods of analysis (16th Edition) Association of official analytical chemists. Washington, D.C.

2. Bae, Y. I. and K. H. Shim. 1998. Nutrition components in different parts of korean loquat (Eriobotrya japonica Lindl.). Korean J. Postharvest Sci. Technol. 5, 57-63.

3. Bae, Y. I., C. H. Jeong, and K. H. Shim. 2002. Nitrite-scavenging and antimutagenic effect of various solvent extract from different parts of loquat (Eriobotrya japonica Lindl.). Korean J. Food Preserv. 9, 92-96.

4. Bae, Y. I., J. S. Moon, and K. H. Shim. 1998. Loquat (Eriobotrya japonica Lindl.) juice processing and its physicochemical properties. Korean J. Postharvest Sci. Technol. 5, 270-274. 
5. Bae, Y. I., K. I. Seo, S. K. Park, and K. H. Shim. 1998. Loquat (Eriobotrya japonica Lindl.) leaf tea processing and its physicochemical properties. Korean J. Postharvest Sci. Technol. 5, 262-269.

6. Blois, M. S. 1958. Antioxidant determinations by the use of a stable free radical. Nature 181, 1199-1203.

7. Borrello, S., M. E. De Leo, and T. Galeotti. 1992. Transcriptional regulation of $\mathrm{Mn}-\mathrm{SOD}$ by manganese in the liver of manganese-deficient mice and during rat development. Biochem Int. 28, 595-601.

8. Cha, Y. G., J. W. Lee, J. H. Kim, M. H. Park, and S. Y. Lee. 2004. Major components of teas manufactured with leaf and flower of Korean native camellia japonica L. Korean J. Med Crop Sci. 12, 183-190.

9. Chae, S. K., G. S. Kang, S. J. Ma, K. W. Bang, M. W. Oh, and S. H. Oh. 2002. Standard food analysis. pp. 381-382, Jigu-Moonwha Sa. Seoul, Korea.

10. Cho, Y. S., S. K. Park, and H. Y. Lee. 1991. Composition of free sugars, organic acids and free amino acids in Loquat flesh. J. Korean Soc. Food Nutr. 20, 89-93.

11. Chung, Y. D., S. I. Hong, H. B. Na, and Y. H. Shim. 1991. The study on concentration of serum copper and zinc in stomach cancer patients. Korean J. Nutr. 31, 324-332.

12. Folin, O. and W. Denis. 1912. On phosphotungastic phosphomolybdic compounds as color regents. J. Biol. Chem 12, 239-249.

13. Gancedo, M. and B. S. Luh. 1986. HPLC analysis of organic acid in Waters. pp. 41-46, PICO. TAG system, Young-in Scientific Co. Ltd., Seoul. Korea.

14. Go, J. K. and S. I. Park. 2005. Sensory property and keeping quality of curd yoghurt added with loquat (Eriobotrya japonica Lindley) extract. Korean J. Food Nutr. 18, 192-199.

15. Gomes, A., J. R. Vedasiromoni, M. Das, R. M. Sharma, and D. K. Ganguly. 1995. Anti-hyperglycemic effect of black tea (Camellia sinensis) in rat. J. Ethnopharmacol. 45, 223-226.

16. Grundy, S. M. 1986. Comparison of monounsaturated fatty acids and carbohydrates for lowering plasma cholesterol. NEng. J. Med 314, 2855-2856.

17. Gutteridge, J. M. 1985. Inhibition of the fenton reaction by the protein ceruloplasmin and other copper complexes: assessment of peroxidase and radical scavenging activities. Chem Biol. Int. 56, 113-120.

18. Huang, M. T., C. T. Ho, and C. Y. Lee. 1992. Phenolic compounds in food. In phenolic compounds in food and their effects on health II. pp 2-7, Maple Press, New York, USA.

19. Husain, S. R., J. Cillard, and P. Cillard. 1987. Hydroxyl radical scavenging activity of flavonoids. Phytochemistry 26, 2489-2491.

20. Jeong, C. H., Y. I. Bae, and K. H. Shim. 2000. Physicochemical properties of Hovenia dulcis Thunb. leaf tea. Korean J. Postharvest Sci. Technol. 7, 117-123.

21. Jeong, C. H., Y. I. Bae, and K. H. Shim. 2002. Chemical components, antioxidative and antimicrobial activities of Chestnut (Castanea crenata) leaves. Korean J. Food Preserv. 9, 234-239.

22. Jeong, Y. S., H. K. Jung, K. S. Youn, M. O. Kim, and J. H.
Hong. 2009. Physiological Activities of the hot water extract from Eriobotrya japonica Lindl. J. Korean Soc. Food Sci. Nutr. 38, 977-982.

23. Jung, K. M., G. H. Kang, M. K. Kwon, I. K. Song, D. H. Cho, and Y. D. Chou. 2004. Chemical components and antioxidant activity of persimmon. Korean J. Food Preserv. 11, 175-181.

24. Kim, B. S., O. J. Choi, and K. H. Shim. Properties of chemical components of Camellia japonica L. leaves according to picking time. J. Korean Soc. Food Sci. Nutr. 34, 681-686.

25. Kim, H. J., C. U. Jo, T. H. Kim, D. S. Kim, M. Y. Park, and M. Y. Byun. 2006. Biological evaluation of the methanolic extract of Eriobotrya japonica and its irradiation effect. Korean J. Food Sci. Technol. 38, 684-690.

26. Kim, H. K., Y. J. Choi, and K. H. Kim. 2002. Functional activities of microwave-assisted extracts from Flammulina velutipes. Korean J. Food Sci. Technol. 34, 1013-1017.

27. Kim, S. L., N. K. Park, and J. R. Son. 2004. Analysis of amino acids. National Institute of Crop Science. R.D.A., 10, pp. 26-40, Suwon. Korea.

28. Korea Food and Drug Association. 2005. Food standards codex. pp. 367-368, 383-385. Korean Foods Industry Association. Seoul. Korea.

29. Lee, C. B. 1982. Korean pictorial book of plants. pp.684-687, Hyangmoonsa. Seoul, Korea.

30. Lee, K. I. and S. M. Kim. 2009. Antioxidative and antimicrobial activities of Eriobotrya japonica Lindl. leaf extracts. J. Korean Soc. Food Sci. Nutr. 38, 267-273.

31. Namba, T. 1994. The encycolopedia of Wakan-Yaku (traditional Sinojapanese medicines) with color pictures. Vol II. pp. 80-82, Hoikusa. Osaka. Japan.

32. Park, S. K., J. K. Kim, J. H. Kim, K. D. Moon, and S. L. Oh. 1994. Study on the characteristic of physicochemical quality of oolong herbs tea by extraction conditions. Korean J. Dietary Culture 9, 411-417.

33. Rice, E. C. A., N. J. Miller, and G. Paganga. 1996. Structure antioxidant activity relationship of flavonoid and phenolic acid. Free Radic. Biol. Med 20, 933-956.

34. Rotruck, J. T., A. L. Pope, and H. E. Ganther. 1973. Selenium: biochemical role as a component of glutathione peroxidase. Science 179, 588-590.

35. Ryu, S. W., C. W. Jin, H. S. Lee, J. Y. Lee, K. Sapkota, B. G. Lee, C. Y. Yu, M. K. Lee, M. J. Kim, and D. H. Cho. 2006. Changes in total polyphenol, total flavonoid contents and antioxidant activities of Hibiscus cannabinus L. Korean J. Med Crop. Sci. 14, 307-310.

36. Son, G. M., S. M. Bae, J. Y. Chung, D. J. Shin, and T. S. Sung. 2005. Antioxidative effect on the green tea and puer tea extracts. Korean J. Food Nutr. 18, 219-224.

37. Van Campen, D. R. 1969. Copper interference with the intestinal absorption of zinc-65 by rats. J. Nutr. 99, 97-104.

38. Whang, T. E., H. O. Lim, and J. W. Lee. 1996. Anticancer effect of Eriobotrya japanica Lindl. by specificity test with several cancer cell lines. Korean J. Med Crop. Sci. 4, 31-320.

39. Wungaarden, D. V. 1967. Modified rapid preparation fatty acid esters from liquid for gas chromatographic analysis. Anal. Chem 39, 848-850. 


\section{초록 : 비파잎의 이화학적 성분과 항산화효과}

황윤경 · 이재준 · 김아라 · 이명렬*

(조선대학교 식품영양학과)

비파잎의 생리활성 기능과 이용 가능성에 관한 연구의 일환으로 비파잎의 영양성분 및 생리활성 효능을 검증 하여 측정한 결과는 다음과 같다. 비파잎의 일반성분은 건량 기준(dry basis)으로 수분 함량 $5.78 \%$, 조단백질 $6.74 \%$, 조지방 $7.87 \%$, 조회분 $6.99 \%$, 식이섬유소 $43.61 \%$, 탄수화물 $29.01 \%$ 를 함유하였다. 비파잎의 구성당은 총 4 종 검출되었으며 이중 rhamnose가 $3,391.84 \mathrm{mg} / 1$ 로 제일 많이 검출되었으며, galactose $663.27 \mathrm{mg} / \mathrm{l}$, glucose $651.65 \mathrm{mg} / \mathrm{l}$, lactose $662.40 \mathrm{mg} / 1$ 검출되었다. 비파잎의 유리 아미노산은 glutamic acid 함량이 $11.30 \mathrm{mg} \%$ 로 가 장 높았으며, asparagine $9.02 \mathrm{mg} \%, \gamma$-amino-n-butyric acid $8.30 \mathrm{mg} \%$, alanine $4.53 \mathrm{mg} \%$, phosphoserine 3.77 $\mathrm{mg} \%$, aspartic acid $3.23 \mathrm{mg} \%$ 순으로 높게 나타났다. 구성 아미노산의 경우 histidine 함량이 $501.26 \mathrm{mg} \%$ 로 가장 높았으며, 총 아미노산에 대한 필수아미노산의 비율은 $50.15 \%$ 로 높게 차지하는 것으로 나타났다. 지방산 중 포화 지방산은 stearic acid가 $41.54 \%$ 로 가장 많이 함유하고 있었으며, lauric acid $12.00 \%$, myristic acid $11.13 \%$, pentadecanoic acid $41.54 \%$ 순으로 검출되었다. 불포화지방산은 oleic acid 만 검출되었으며, 총 지방산 함량의 $27.9 \%$ 를 함유하고 있었다. 비타민 A는 $0.039 \mathrm{mg} \%$, 비타민 $\mathrm{E}$ 는 $0.096 \mathrm{mg} \%$, 비타민 C는 $0.575 \mathrm{mg} \%$ 로 검출되었다. 무기질 은 $\mathrm{Ca}$ 함량이 $1,892.60 \mathrm{mg} \%, \mathrm{~K}$ 함량이 $1,244.90 \mathrm{mg} \%$ 로 많이 검출되었다. 다음으로 $\mathrm{Mg}, \mathrm{Na}, \mathrm{Mn}, \mathrm{Zn}$ 순이었고, $\mathrm{Cu}$ 함량은 미량 함유하는 것으로 나타났다. 비파잎의 유기산은 succinic acid 함량이 24,343.57 mg/1로 가장 많았 고, 다음으로 citric acid 2,964.87 mg/l, maleic acid $2538.59 \mathrm{mg} / \mathrm{l}$ 순으로 검출되었다. 비파잎 에탄올 추출물의 기능성을 측정한 결과 총 polyphenol 함량은 $500 \mathrm{ppm}$ 에서 $15.77 \mathrm{mg} / \mathrm{ml}, 1,000 \mathrm{ppm}$ 에서 $32.32 \mathrm{mg} / \mathrm{ml}$ 함유하고 있는 것으로 나타나 $1,000 \mathrm{ppm}$ 에서 약 2배 정도 높게 나타났다. 총 flavonoid 함량은 $500 \mathrm{ppm}$ 에서 $15.58 \mathrm{mg} / \mathrm{ml}$, $1,000 \mathrm{ppm}$ 에서 $28.65 \mathrm{mg} / \mathrm{ml}$ 으로 나타났다. 비파잎의 DPPH radical 소거능은 $500 \mathrm{ppm}$ 에서 $68.26 \%, 1,000 \mathrm{ppm}$ 에서 $80.53 \%$ 소거능을 보였으며, 이는 농도가 증가함에 따라 항산화 활성도 증가되는 것을 알 수 있었다. 특히 $1,000 \mathrm{ppm}$ 에서 대조구인 $500 \mathrm{ppm} \mathrm{BHT} \mathrm{및} \mathrm{BHA와} \mathrm{비슷한} \mathrm{수준으로} \mathrm{높은} \mathrm{항산화} \mathrm{활성이} \mathrm{나타났다.} \mathrm{이상의} \mathrm{결과}$ 비파잎은 필수아미노산 및 항산화 비타민, 무기질을 다량 함유하고 있으며 비파잎 에탄올 추출물은 항산화 활성 및 DPPH radical 소거능이 우수한 것으로 나타나 비파잎을 이용한 기능성 식품의 개발가치가 한층 더 높아질 것으로 기대되어 진다. 